\title{
HISTORY AND DEBUT OF THE SKI-MOUNTAINEERING
}

\author{
Fabiana MARTINESCU-BĂDĂLAN \\ martinescu-fabiana@yahoo.com \\ Robert STĂNCIULESCU \\ rstanciulescu@armyacademy.ro \\ “NICOLAE BĂLCESCU” LAND FORCES ACADEMY, SIBIU, ROMANIA
}

\begin{abstract}
Since ancient times, skiing has been a way of moving, born out of a spirit of survival. The usefulness of this means of transportation has undergone numerous transformations with implications in terms of utility-applied aspect as well as in the area of sports and recreation. Military Physical Education, as a component of military training, includes utility-applied skiing, focusing in particular on cross-country skiing and ski touring. The modern battlefield requires military training in increasingly complex and new areas in this century, with a focus on the formation of well-trained and multispecialized armies of professionals, to the detriment of mass armies. Ski-mountaineering has increasingly evolved over the last few years, due to the possibility of reaching relatively fast on the ridge tips and lowering even faster, eliminating the barriers imposed by the relief. As the name calls it, it combines the techniques and procedures of skiing with mountaineering.
\end{abstract}

\section{KEYWORDS:}

History, skiing, climbing

\section{The history of skiing}

Skiing dates back to the oldest times, with an approximate age of 7000 years, according to cave drawings found in the Scandinavian Peninsula. The development of this process by cavemen was determined by the necessity of gathering food and hunting in the polar and subpolar environment of the Nordic countries. The oldest skis were found in a swamp in Sweden, their carbon footprint dating back 4500 years ago (Dawson, 1997).
Zenophon, a Greek historian and a military leader, mentions skis in one of his own works in the year 500 BC. In 1206, military skiers rescued Norway's monarchy when they escorted King Haakonson, who at that time was a minor, to a safe area over the mountains during the Norwegian Civil War. Ten years later, the skis helped Norwegians expel the Swedish Army outside the country. Thus, Norwegian culture adopted the skis, Norway being the spiritual father of the ski, both as a sport 
and as a way tomove on snow, until Austrian Hannes Scheider won his first ski competition in Gridelwald 700 years later (Dawson, 1997).

The Scandinavians (who previously used the process of skidding in military conflicts) began to use skiing for fun. They were also innovators of the necessary equipment. In 1557 A. D. historian Olaus Magnus describes in his work "Historia de gentibus septentrionalibus" how the Scandinavian skiers used climbing techniques to climb the slopes "when they climbed in a place they did not slip behind because they used animal skins on the bottom of the skis whose hair raised like the spears, or brushes and the admirable force of nature did not let them slide back" (Dawson, 1997, pp. 1-3).

"Physical exploration of the world was growing rapidly during the Romantic Period, the time of Wordsworth. Early mountaineers were upper class and well educated: poets, photographers, geologists, painters and natural historians" (House \& Johnston, 2014, p. 18).

In the mid- $19^{\text {th }}$ century, a young Norwegian farmer and skier jumper named Sondre Norheim (1825-1897) felt a need to find a solution for better control of his skis. He took a piece of a birch root and wrapped it around both the toes of the foot and around the boot heel, also building some shorter skis with some cuts. Until then, the bindings were simple pieces of material bound around the tip of the boot. Norheim is also the inventor of the well-conceived skiing style called Telemark, named after Norheim's hometown, Telemark. He also, with his friends, redefined the technique previously used for skiing downhill, finding a position where the skis were parallel and a turn was made in which there was a change of weight from one foot to the other, accomplished by genuflexion. This turn was called Christiania. Even though the Telemark had an impressive effect at that time, yet both styles of ski remained (Dawson, 1997).
The Telemark became so popular because it was effective when landing at the time of the ski jumping and was a way to make the turns with that primitive equipment. Christiania also offered a much faster stop and a closer turn.

Another great pioneer of skiing is Mathias Zdarsky, who in 1896, in the Austrian Alps, developed a technique different from that of Norheim, which allowed the descent on more steep slopes. This technique consists in the skidding of skis, which results in an exponential increase in the speed of movement (Schi-şisnowboard, 2014).

The ski touring begins with an expedition in the Switzerland Alps in 1890 and is organized by the Swiss Christoph Iselin and the German Wilhelm Paulcke (Schi-şi-snowboard, 2014).

In 1900, Hannes Schneider, an Austrian skier, using the ski discoveries developed by Zdarsky, created a technique called Alberg, which improved the turn and stop. Hannes Schneider was the one who founded the skiing methodology. His passion for skiing has been evident since adolescence, when he became an instructor at a ski school in St. Anton. Viktor Sohm, the creator of the ski wax idea, was Schneider's mentor during his childhood. Scheinder will combine existing methods and techniques by then and comes with a comprehensive and new idea in terms of learning and practicing skiing. The Telemark remains as a didactic practice. He defines the Christianiaas a bypass to the valley that requires keeping the skis parallelly. He develops a pedagogical system, organized by groups of beginners and advanced and defines the levels to be covered in skiing (Schi-şi-snowboard, 2014).

During this time, when Norheim redefined the ski technique in the northern countries, in North America, in the Sierra Nevada Mountains, Norwegian immigrants in the mining field developed a totally different ski technique (the Scandinavian influence on North America regarding 
skiing has a long tradition, beginning with Leif Ericson, the Viking king who colonized North America in the 1000th A.D.). These miners generally used skis for transport, but began a series of dangerous straight-line descents, reaching speeds of up to $80 \mathrm{miles} /$ hour using some $3.65 \mathrm{~m}$ skis, called "longboards" (Dawson, 1997).

During the same period, 1848-1873, other discoveries in the field of skiing were in full swing. At first, mountaineering was more of a recreation than a way to explore. The golden age of mountaineering began in Europe with the first ascent of the Wetterhorn in 1854, 11 years later, and the Matterhorn was conquered by Edward Whymper (Dawson, 1997).

We can not go through skiing history without remembering Fridtjof Nansen, a prophet and a pioneer of this sport. He was a Norwegian intellectual, explorer and scientist and the most enthusiastic visionary of skiing throughout history. His first target was Greenland in 1888, where he managed to complete a crossing of 300 miles on skis. Afterwards, in 1893, he almost managed to reach the North Pole, moving both with boats and kayaks, and using skis, being closer than no other until that date (Schi-şisnowboard, 2014).

\section{Skiing and climbing in Romania}

"Climbing is a dangerous sport that carries with it the risk of injury or death. Climbing safely requires good judgement based on experience, competent instruction, and a realistic understanding of your personal skills and limitations" (Houston \& Cosley, 2004, p. 11).

Climbing in Romania has its debut in 1873, when SAK (Alpine Club of Transylvania - Brasov) was established. In 1881 it changed its name to SKV (Transylvanian Carpathian Society). After this time more and more tourists came to the mountain for trips and relaxation. As a result of these events, the first shelters on the mountain huts/hideaways, dedicated to tourists, began to appear, according to the patterns of the Alps "...the initial moment of the Romanian climbing, is considered to be the trip in 1903 [on the Horoabei valley, Bucegin.n], having as protagonists Jerome, Nicolae Bogdan and Mihai Haret..." (Borda, 1976, p. 24).

Winter sports have enjoyed great visibility since the twentieth century, when the exploration of the mountains, ski holidays became a fashion. Several contests have begun to be organized at country level, which led to the achievement of records and performances. The royal family was one of the promoters of these sports in the country, being both practitioners and developers. Carol II and his successor, Mihai, loved skiing and were exceptional skiers (Schisnowboard, 2014).

"The modern form of mountaineering in our country began in 1912, when for the first time the northern wall of the Gălbenelelor Valley, the central split in Bucegi, the edges of Piatra Craiului and the classic Piatra Altaruluipath in Ceahlău..." (Suman \& Babadag, 1987, p. 39).

"In 1920, the first skiing association in Brasov is being certified in Romania. In fact, the 1880 society, named 'Karpathia'. In 1892 there was a group of Romanian skiers, led by Carol Ganzert, who were skiing at Clăbucetele Predealului" (Schi-şi-nowboard, 2014).

Also, skiers were certified in Cluj County, skiing in Mount Băişorii, Feleac, Bihor and Vârtop. A record-breaking distance from Cluj to Turda was covered, $35 \mathrm{~km}$ on skis.

Members of the SKV organization have found a favorable region for the development of ski slopes in Braşov County, namely Poiana Soarelui, now known as Poiana Braşov.

At that time, Princess Ileana was a student at the National Academy of Physical Education and participated in the ski camps organized by the Academy in the Valea Prahovei.

"The two great promoters of skiing are Captain Pălăngeanu and Th. Rosetti- 
Solescu. They organize courses and competitions in Târgu Neamţ, Tihuţa and Postăvaru. Theodor Rosetti Solescu is the one who organized the first ski courses for the newly established 'vânătorii de munte' branch [elite mountain troops of the Romanian Land Forces n.n.] (1915, 19171920), also publishing the first skiing manual in Romanian, 'Skier's Handbook' (1920)" (Schi-şi-snowboard, 2014).

\section{The use of skis during war years}

Moving from a general history of skiing techniques and procedures to their military history, the importance of using skis in armed conflicts and their applicability in the military environment.

"Climbers in particular are adopting skis as a better tool for accessing rock, ice, and mixed-climbing objectives. The net effect of all these factors is that more and more people are looking outside the skiarea boundaries for their skiing experiences" (Volken, Schell \& Wheeler, 2007, p. 7).

In the Romanian army, on September 30, 1916, the first mountain structure was established, namely the Ski School, in the city of Bucharest, in the $4^{\text {th }}$ Roşiori Regiment, where about 1,000 soldiers were trained. "According to Order no. 294 of 3 November 1916 of the General High School, the School of Skiing in Bucharest was transformed into the Mountain Troops Corps, a unit organized on three battalions, each having three companies, totalling 1980s" (Suman, 2003, pp. 17-40).

Regarding the inclusion of these troopers and climbers in the combat environment, they have acted in both world wars and in the theatres of contemporary operations.

Being set up in the middle of the war, mountain troops started the campaign with a march from Bucharest, from the $4^{\text {th }}$ Roşiori Regiment, to Târgu Neamţ, determined by the German offensive coming from the west of the country. The loss of the alignment on Arges by the Romanian army favored the very rapid advance of the
German army to the capital of the country. Bucharest was totally evacuated, being surrendered without a fight, the new alignment being established on the directions of Nămoloasa-Galaţi.

On December 27, 1916, the Vânătorii de Munte Corps was turned into the Vânătorii de Munte Battalion. Under the strict supervision of the French Mission officers, the battalion was reorganized, equipped and trained to carry out future operations.

These troops have undergone a series of changes due to the need to ensure the Carpathian chain, especially after the Union of December 1, 1918, where the entire Carpathian arch appeared in the new map. The $2^{\text {nd }} V M$ Brigade was established with two regiments of three battalions. Also, a training center has been set up at Zărnești.

In the post-war years, the emphasis was particularly on the training of these elite mountain troops, especially on the preparation of mountain fighting in the winter. In 1931, a ski center was set up at Dorna Candrenilor, where Major Leonard Mociulschi was named commander. The ski center was structured for four weeks, with a total of 76 hours. These hours consisted of the technical instruction of climbing, the technical training of the soldier, the training of the soldier, the training of the group of skiers, the training of the skier platoon, the training of the ski detachment, winter campaigning in the mountains, shooting in the mountains in winter time, skiing and also orientation and dangers in the mountains (Suman, 2003, p. 17-40)

At the beginning of the Second World War, the Romanian Vânători de Munte, who demonstrated their efficiency, courage and bravery on the fronts of the First World War, were organized and structured on four brigades, namely Brigades 1, 2, 3, 4 Mixed Mountain, one of the brigades being deployed at the Hungarian border (3 Mountain Joint Brigade, later the mountain brigades were transformed into divisions, developing very high operational features). The mountain 
divisions fought on the eastern front, reaching the foothills of the Caucasus Mountains. The efficiency of these troops, rendered by their high degree of mobility, was also proven in the Battles for Stalingrad and Sevastopol.

\section{Conclusions}

From what we have seen above, it is clear that ski climbing is a multidisciplinary niche. You need to have solid knowledge of the equipment you need to use, the structure of the snow, the dangers that may arise, and the assessment of the safety measures.

One must also have solid knowledge of the elements of "setting up protections in various environments such as snow, rock, ice, rope manoeuvres, insurance techniques, ski climbing technique, crampons and ice axe technique, descent technique on different types of snow, planned bivouac or emergency, choosing an optimal route" (Vălean, 2008).

Ski-mountaineering combines a range of techniques that will actively contribute to the formation of capable soldiers to overcome the limits imposed by the alpine and arctic environment, motivating them to reach the top regardless of its physiognomy.
"Activities that are carried out in the mountains are continuously developing as people constantly look for different challenges. Ski touring and ski mountaineering have always been there for, what at one time was the specialist, but with progress being made in the development of equipment, culled with a more affluent society and a more health conscious public who seek quality free-time away from work, ski touring and ski mountaineering are being rediscovered by the masses" (Branigan \& Jenns, 2013, p. 38).

We can describe this sport as an extreme one, both in high risk areas and as snow types vary from one hour to the next in alpine areas. If during the morning the snow is strong and ice and wind can occur, mid-day the snow may become soft or cumbersome due to the increase in temperature, thus increasing the risk of avalanches.

Ski-mountaineering is generally an activity where the skier follows the climb, from the base of a mountain or a slope to the top, using techniques related to skiing and mountaineering, following its descent using the Christiania or Telemark.

\section{REFERENCES}

Borda, V. (1976). Călătorie prin vreme. București: Sport-Turism.

Branigan, H., \& Jenns, K. (2013). A complete guide to alpine ski touring ski mountaineering and nordic ski touring. USA: Author House, IN.

Dawson, L.W. (1997). Wild Snow. Salt Lake City, UT, USA: AAC PRESS.

House, S., \& Johnston, S. (2014). Training for the New Alpinism: A Manual for the Climber as Athlete. Ventu, CA, USA: Patagonia Books.

Houston, M., \& Cosley, K. (2004). Alpine Climbing: Techniques to Take You Higher. Seattle, WA, USA: The Mountaineers Books.

Ski-si-snowboard. (2014). Istoria schiului. De la legende până azi, available at: http://ski-si-snowboard.ro/editoriale/istoria-schiului-de-la-legende-pana-azi-1700, accessed on 09 January 2019. 
Suman, G. (2003). Istoria Brigăzii 2 Vânători de munte "Sarmisegetuza”. Bucureşti: Pro-Transilvania.

Suman, G., \& Babadag, D. (1987). Alpinismul, şcoală a cutezanţei. Bucureşti: Editura Militară.

Vălean, A. (2008). Ski de tură, ski alpinism şi despre avalanşe. Blog-Snow Trance, available at: http://snow-trace.blogspot.com/2008/10/despre-ski-de-tura-si-ski-alpinism.html, accessed on 09 January 2019.

Volken, M., Schell, S., \& Wheeler, M. (2007). Backcountry Skiing: Skills for Ski Touring and Ski Mountaineering. Seattle, WA, USA: The Mountaineers Book. 